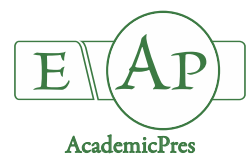

\title{
Non-Destructive Leaf Area Estimation Model for Overall Growth Performances in Relation to Yield Attributes of Cassava (Manihot esculenta Cranz) under Water Deficit Conditions
}

\author{
Piyanan PIPATSITEE, Apisit EIUMNOH, Patchara PRASEARTKUL, \\ Navavit PONGANAN, Kanyarat TAOTA, Sumaid KONGPUGDEE, \\ Kampol SAKULLEERUNGROJ, Suriyan CHA-UM*
}

\author{
National Center for Genetic Engineering and Biotechnology (BIOTEC), National Science and Technology Development Agency (NSTDA), 113 \\ Thailand Science Park, Phahonyothin Road, Khlong Nueng, Khlong Luang, Pathum Thani 12120, \\ Thailand; suriyanc@biotec.or.th; suriyanc7@gmail.com ("correspondingauthor)
}

\begin{abstract}
Cassava is a tropical storage root crop, a source of carbohydrate and alternative energy. It has been classified as "drought tolerant plant" for the whole life cycle, except during the root initiation stage (120-150 DAP). Leaf area index (LAI) is one of the most parameters representing the overall growth and yield prediction in cassava. The aim of this investigation was to validate the physiological and growth performance of cassava in responses to water deficit stress in the field trial as well as to investigate the leaf area index as an important factor to cassava growth and storage root bulking. Leaf relative water content in cassava declined significantly upon a long period of water withholding, and regulated non-photochemical quenching (NPQ), leading to chlorophyll degradation, reduced number of leaves and limited leaf area index (LAI) and loss of storage root yield when compared with well-irrigated plants. Non-destructive leaf area estimation model under water deficit stress condition using spectral reflectance to determine the LAI and VIs was validated. The Ratio Vegetation Index (RVI) was suitable model with high coefficient of determination $\left(\mathrm{R}^{2}=0.89\right)$. However, the RVI as LAI at $150 \mathrm{DAP}(120 \mathrm{~d}$ water withholding $)$ could be considered as the critical point to indicate cassava growth and yield performance. Based on the results, cassava growth, biomass and yield in the different environments may further be investigated, taking into consideration the genotypic variation and using remote sensing technology for rapid monitoring and accurate and cost-effective data assessment.
\end{abstract}

Keywords: cassava; growth performances; leaf area index; non-destructive model; vegetation indices

\section{Introduction}

Loss in the yield of crops such as cereals, legumes, tubers and root crops due to the drought incidents borne out of global climate change are evidently demonstrated in several regions of the world (Daryanto et al., 2017). In tuber crops (potato and cassava), the storage root initiation is more sensitive to drought stress than vegetative developmental stages (Daryanto et al., 2016). Cassava (Manihot esculenta Cranz), one of the top five crops used for global starch production, played a key role in bio-based fuel as bioethanol for $150 \mathrm{~L}_{\text {tonne }}{ }^{-1}$ or 6,000 L ha ${ }^{-1}$ year $^{-1}$ (Jansson et al., 2009; Ziska et al., 2009; Numamanya et al., 2012), especially in Thailand (3.4 million litres per day; Nguyen et al., 2007). Previously, cassava has been identified as a drought tolerant plant that can withstand the dry season for 4-6 months, depending upon the evaporation rate (Oguntunde, 2005), available soil water (irrigation schedule) (Pardales and Esquibel, 1996), and genotypic variation (El-Sharkawy, 2007; Okogbenin et al., 2013). However, it was reported by many physiological studies that net photosynthetic rate, stomatal conductance, transpiration rate and water use efficiency in cassava grown under drought conditions significantly declined when compared with well-irrigated plants (Itani et al., 1999; El-Sharkawy, 2007). In addition, overall growth performances of both shoot and root traits are affected, depending on the level of drought stress (ElSharkawy, 2007; Duque and Setter, 2013).

Leaf area, leaf retention and leaf area expansion rate in cassava is related to its productivity, especially during the water shortage (Alves and Setter, 2000; Alves and Setter, 2004; Lenis et al., 2006). Leaf area index (LAI) is an indicator of leaf area per unit ground area (Jonckheere et al., 2004) and is regulated by the genotype, plant age, 
environment, management practices and cropping system (Ekanayake et al., 1998). In cassava, leaf area is a key indicator of crop growth rate and the storage bulking rate (Cock et al., 1979a). Leaf area of cassava depends on number of branches, number of leaves, leaf expansion and leaf retention. In general, the leaves are produced within 90 to 120 days after plantation (DAP) and the maximum total leaf area is achieved within 120 to 150 DAP. The rate of leaf formation is decreased depending on plant developmental stage from initiation to maturity. An optimal leaf area index (LAI) for storage root bulking is 3.0 to $3.5 \mathrm{~m}^{2} \mathrm{~m}^{-2}$ ground area (Hillock et al., 2001). In Thailand, the optimal LAI for starch formation is $4.0 \mathrm{~m}^{2} \mathrm{~m}^{-2}$ as well as the net photosynthetic rate decreases depending upon the level of shade (Boonseng, 2008). In a recent study, simulating impact model of cassava grown under drought stress (short-, long-water stress and recovery) has been reported using the LINTUL in relation to LAI (Ezui et al., 2018).

Non-destructive Leaf Area Estimation model has been investigated and validated in several crop species, such as jatropha (Pompelli et al., 2012), kiwi (de Gyves et al., 2007), hazelnut (Cristofori et al., 2007), Persian walnut (Keramatlou et al., 2015), apple (Sala et al., 2015), teak (Tondjo et al., 2015), soybean (Bakhshandeh et al., 2011) and faba bean (Peksen, 2007). In two morphotypes of cassava (Philippine and Nagra), linear regression models of leaf number prediction have been validated (Fakir et al., 2011). Several methods of LAI measurements have been developed, directly from the leaf area measurements or indirectly through a non-destructive measurement. Direct methods are accurate but labor intensive and therefore, have a limited use. When the number of plants is limited, the estimation of LAI using nondestructive method is better, simple, quick, accurate, reliable and inexpensive procedure (Wiersma and Bailey, 1975). In addition, the remote sensing has been used to estimate LAI and it changes to the broadband spectrum (Boonyanuphap, 2014). Spectral indices or vegetation indices (VIs) are the new variables generated by mathematical combinations of two or more original spectral bands of the biophysical parameters such as canopy LAI, water content, pigment, etc. (Jone and Vaughan, 2010; Reynolds et al., 2011). The relationship between Normalized Difference Vegetation Index (NDVI) and LAI in case of paddy rice, pearl millet sugar cane, pasture, corn, eucalypt and riparian forest were found to be the best potential models (Xavier and Vettorazzi, 2004; Vijendra and Chandra, 2012; Xiao et al., 2012). The Normalized Difference Water Index (NDWI), NDVI and the Gitelson-Merzlyak Index (GMI) of almonds also showed a high correlation with LAI (Jose et al., 2012). Moreover, the studies based on the variations in leaf area values under salinity and water stress conditions in green pepper, tomato and cucumber have also been undertaken (Cemek et al., 2011; Hossain et al., 2017). Therefore, the best estimated model in cassava crop has still been limited in the literatures. The present study has been conducted to investigate the crop responses towards prolonged drought conditions. We used VIs for estimated LAI of cassava to indicate overall growth performances and yield attributes in the field trial under well-irrigation and water deficit condition.

\section{Materials and Methods}

\section{Experimentalsite and design}

The experiment was carried out at the Thai Tapioca Development Institute area, Nakhon Ratchasima province, Thailand $\left(15^{\circ} 09^{\prime} 09.8^{\prime \prime} \mathrm{N}, 101^{\circ} 29^{\prime} 42.8^{\prime \prime} \mathrm{E}\right)$ between February - December 2014. Cassava [Manihot esculenta cv. 'Huay Bong 80' (KU50 $\times$ Rayong 5) yield $=30.6-34.4$ ton ha ${ }^{-1}$, and starch content $=27.3 \% \mathrm{w} / \mathrm{w}]$; Vichukit et al., 2011] was planted in the field. The experimental design was a completely randomized design (CRD) under well-watered (WW) and water-stressed (WS) conditions with three replications in a $16 \times 16 \mathrm{~m}$ plot. The plant and row spacing was maintained 0.8 and $1.2 \mathrm{~m}$, respectively. Soil texture of the area is sandy clay loam in the top $0.50 \mathrm{~m}$ (sand 59\%, silt $16 \%$, clay $25 \%$, pH 6.7, $\mathrm{EC}_{\mathrm{e}} 0.39 \mathrm{dS} \mathrm{m} \mathrm{m}^{-1}$, OM $1.15 \%$, available P $31.85 \mathrm{mg} \mathrm{kg}^{-1}$ and exchangeable $\mathrm{K} 161.99 \mathrm{mg}$ $\left.\mathrm{kg}^{-1}\right)$. The moisture at field capacity and permanent wilting point were 29.12 and $11.49 \% \mathrm{Vol}$, respectively. The chemical fertilizer $\left(15-7-18 \mathrm{~N}-\mathrm{P}_{2} \mathrm{O} 5-\mathrm{K}_{2} \mathrm{O}\right)$ was used at the rate of $312.5 \mathrm{~kg} \mathrm{ha}^{-1}$ at 1 month after plantation (MAP). The online soil moisture sensors (ML3 ThetaProbe Soil Moisture Sensor, $\Delta \mathrm{T}$ Delta-T Devices, London UK) were installed at $15 \mathrm{~cm}$ depth from soil surface in WW and WS plots for estimating the soil moisture enclosing the cassava root zone. WS plot was applied with the sprinkle irrigation at weekly intervals up to $1 \mathrm{MAP}$ and thereafter, no irrigation was provided until harvesting process. WW plot was irrigated with the sprinkle (@2 $\mathrm{m}^{3} \mathrm{~h}^{-1}$ for $2 \mathrm{~h}$ ) to maintain soil moisture at $80 \%$ of available water (AW) or $25 \% \mathrm{Vol}$ during the whole experiment (10 d interval using 4 $\mathrm{m}^{3}$ per $6.28 \mathrm{~m}^{2}$ ). The weather station was installed near the experimental plot to collect the solar radiation, wind speed, air temperature, air relative humidity and rainfall that ranged from 84 to $348 \mathrm{MJ} \mathrm{m}^{-2}, 1$ to $19 \mathrm{~km} \mathrm{~h}^{-1}, 25$ to $31{ }^{\circ} \mathrm{C}$ and 63 to $93 \% \mathrm{RH}$, respectively. The total rainfall during the field trial was $690 \mathrm{~mm}$ (Fig. 1).

\section{Field measurements}

LAIs were measured every month from 60 DAP until 240 DAP using LI-COR LAI-2000 Plant Canopy Analyzer (Fig. 2). The LAI-2000 was used as a fisheye light sensor that measured by making a reference reading above the canopy (sensor aimed up at the sky), and one or more readings beneath the canopy (sensor again looking up). The below canopy readings were divided by the above canopy readings to obtain an estimate of the gap fraction at the five angles. The sensors were always shaded from direct sun when in use (Welles, 1990). LAI was computed using the ellipsoidal inversion model and integrated into the LAI2000 software program, and easily applied to the PAR data collected in the field (Peper and McPherson, 1998). In this research, LAI measurements were conducted within the middle five rows of the plot using one-above and four-below canopy readings. The LAIs were calculated to represent each plot and were used for the estimation and validation of the model.

Measurements of spectral reflectance were started from $60 \mathrm{DAP}$ and continued until $240 \mathrm{DAP}$. The measurements were carried out over two data set using Field Spectroradiometer, Fieldspec 3 (ASD), within a spectral 
582

range of 350 to 2,500 $\mathrm{nm}$. Measurement has also defined field of view (FOV) at $25^{\circ} \mathrm{FOV}$ at $1.5 \mathrm{~m}$ that cover above the canopy and ground about $0.67 \mathrm{~m}$. Within each plot, the spectral reflectance was measured 6 plants during $11.00 \mathrm{~h}$ to 14.00h, on a clear sunny day (Reynolds et al., 2011; Pask et al., 2012). The average reflectance values were calculated as the estimated VIs for estimation and validation of the model.

Relative water content (RWC) was measured in the fully expanded leaves. Leaf discs of about $5-10 \mathrm{~cm}^{2}$ were cut from each sample and weighed to obtain the fresh weight (FW). After that the samples were immediately hydrated to full turgidity for $4 \mathrm{~h}$ under room conditions. After $4 \mathrm{~h}$, the samples were taken out of the water, well dried of any surface moisture quickly and lightly with a filter paper and immediately weighed to obtain fully turgid weight (TW). Samples were then oven-dried at $80^{\circ} \mathrm{C}$ for $24 \mathrm{~h}$ and weighed after cooling down to determine dry weight (DW). The RWC was calculated as:

RWC $(\%)=[($ FW-DW $) /($ TW-DW $)] \times 100$

where the FW is fresh weight, TW is turgid weight and DW is dry weight of sample.

Leaf greenness in the second expanded leaf of both WW and WD treatments in each time point was measured using SPAD-502Plus (Konica Minolta, Japan) following the method of Uddling et al. (2007).

Chlorophyll fluorescence emission was measured from the adaxial surface of second expanded leaf using a fluorescence monitoring system (model FMS 2; Hansatech Instruments Ltd., Norfolk, UK) in the pulse amplitude modulation mode (Loggini et al., 1999). A leaf, kept in dark for $30 \mathrm{~min}$, was initially exposed to the modulated measuring beam of far-red light (LED source) with typical peak at a wavelength of $735 \mathrm{~nm}$. Original $\left(\mathrm{F}_{0}\right)$ and maximum $\left(\mathrm{F}_{\mathrm{m}}\right)$ fluorescence yields were measured under
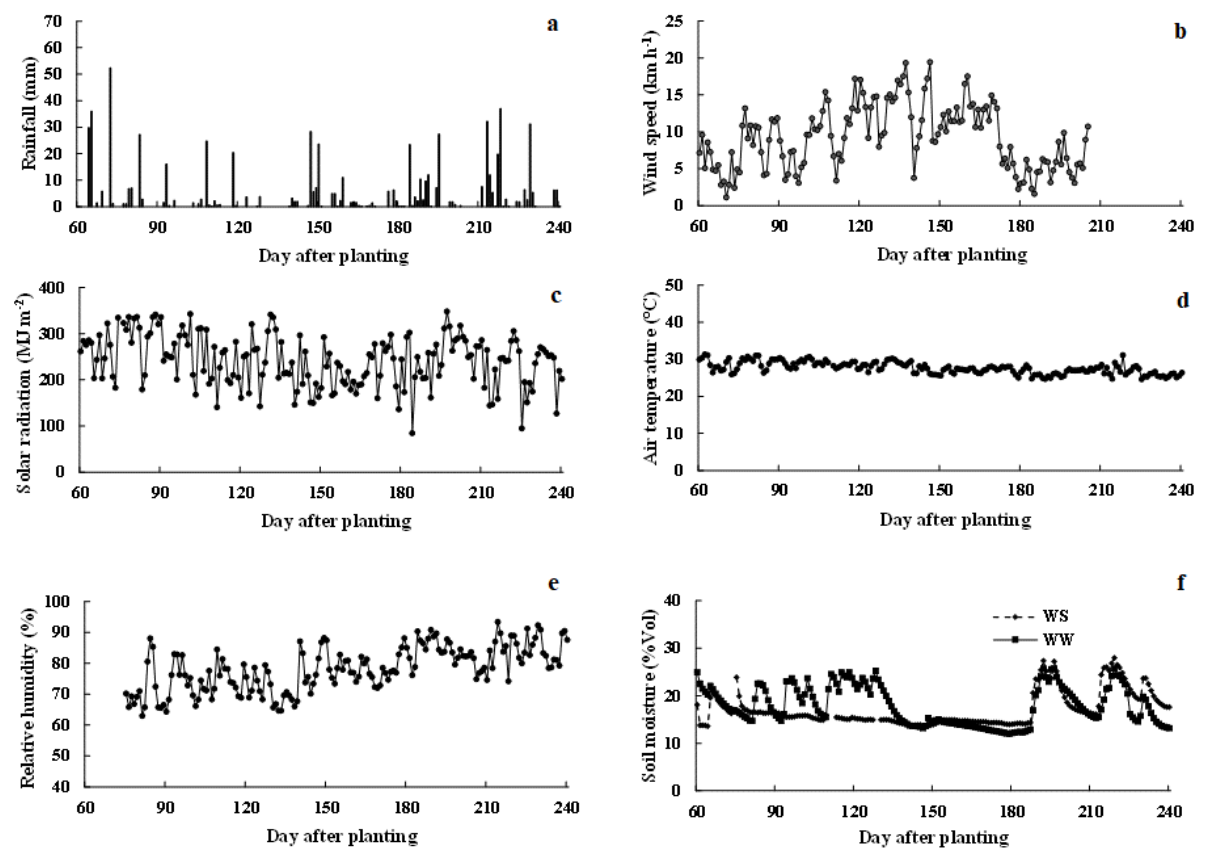

Fig. 1. Rainfall (a), wind speed (b), solar radiation (c), air temperature (d), relative humidity (e) and soil moisture content (f) in the field trial of cassava. 

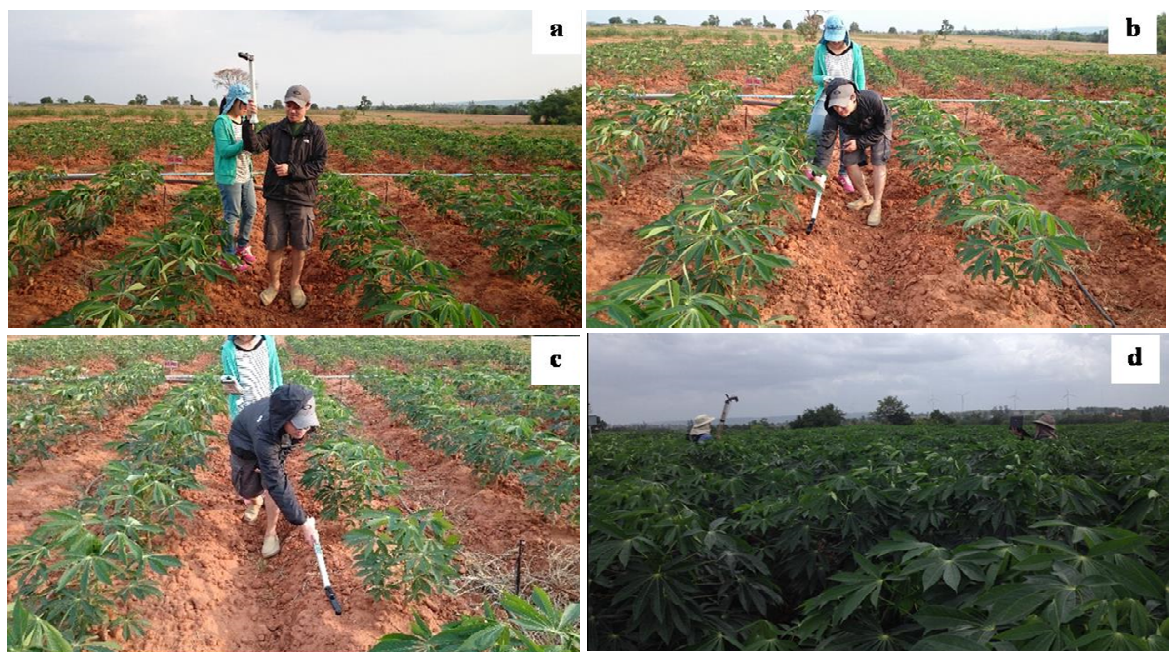

Fig. 2. Leaf area estimation in the cassava plantation in above canopy (a), below canopy in first row (b), below canopy in second row after planting for 2 months and overall measurements after planting for 4 months (d) using LI-COR LAI-2000 Plant Canopy Analyzer

Table 1. Vegetation indices (VIs) used in this research

\begin{tabular}{|c|c|c|c|}
\hline VIs & Name & Equation & Reference \\
\hline NDVI & $\begin{array}{l}\text { Normalized difference vegetation } \\
\text { index }\end{array}$ & $(\mathrm{NIR}-\mathrm{R}) /(\mathrm{NIR}+\mathrm{R})$ & Rouse et al. (1974) \\
\hline RVI & Ratio vegetation index & $\mathrm{NIR} / \mathrm{R}$ & Jordan (1969) \\
\hline EVI & Enhanced vegetation index & $2.5[(\mathrm{NIR}-\mathrm{R})) /(\mathrm{NIR}+6 \mathrm{R}-7.5 \mathrm{~B}+1)]$ & Huete et al. (2002) \\
\hline SAVI & Soil-adjusted vegetation index & $(\mathrm{NIR}-\mathrm{R}) /(\mathrm{NIR}+\mathrm{R}+\mathrm{L})(1+\mathrm{L}) ; \mathrm{L}=0.5$ & Huete (1988) \\
\hline VARI & $\begin{array}{l}\text { Visible atmospherically Resistant } \\
\text { Index }\end{array}$ & $(\mathrm{G}-\mathrm{R}) /(\mathrm{G}+\mathrm{R}-\mathrm{B})$ & Gitelson et al. (2002) \\
\hline MTVI2 & $\begin{array}{l}\text { Modified second triangular } \\
\text { vegetation index }\end{array}$ & $\frac{1.5[1.2(N I R-G)-2.5(R-G)]}{\sqrt{(2 \times N I R+1)^{2}}-(6 \times N I R-5 \times \sqrt{R)-0.5}}$ & Haboudane et al. (2004) \\
\hline
\end{tabular}

$\mathrm{NIR}=$ Near Infrared; $\mathrm{R}=$ Red band; $\mathrm{G}=$ Green band and $\mathrm{B}=$ Blue band .

Supplementary 3). Mean values in each parameter were compared using $t$-test. The root mean square error (RMSE) for the measured LAI was assessed using the equation below.

$$
R M S E=\sqrt{\frac{\sum_{i=1}^{n}\left(X_{o b s, i}-X_{\text {model }, i}\right)^{2}}{n}}
$$

where $X_{o b s}$ refer to the observation samples at $i, X_{\text {model }}$ refer to the model samples at $i$ and $\mathrm{n}$ refer to the number of samples. Calibrated calculated model using exponential equation was validated (Fig. Supplementary 2).

\section{Results}

Growth performances, physiological changes and yield attributes in response to water deficit

Number of leaves in cassava was significantly dropped in plants grown under water deficit conditions (Fig. 3a). At $150 \mathrm{DAP}$ (120 d water withholding), number of leaves in water deficit stressed plants was $15.34 \%$ lower than that in WW plants (Table 2). It was evidently demonstrated that the number of fallen leaves was promoted by adaptive period of water deficit, leading to decrease LAI parameter. LAI in both WW and WS conditions increased in relation to the growing period. In addition, the reduction percentage of LAI in WS cassava at 150 DAP was $34.32 \%$ lesser than WW plants (Table 2). Shoot height was represented as overall growth performances of cassava, which was a sensitive parameter to water deficit stress. Shoot height in cassava was significantly increased with the developmental stages in both WW and WS treatments (Fig. 3c). In water deficit stressed plants at 150, 180 and 210 DAP, shoot height was significantly declined by $31.63 \%, 13.99 \%$ and $15.43 \%$, respectively (Table 2). RWC in the leaf tissues was maintained in WW plants, whereas it was significantly declined by $21.44 \%, 29.23 \%$ and $31.33 \%$ when exposed to water withholding for 90 (120 DAP), 120 (150 DAP) and $150 \mathrm{~d}$ (180 DAP), respectively (Table 2 and Fig. 3d).

Total chlorophyll content or greenness of leaves was retained in the early period (60-120 DAP) of water withholding and subsequently degraded by $8.17 \%, 4.44 \%$, $6.31 \%$ and $9.90 \%$ when subjected to water withholding for 150, 180, 210 and $240 \mathrm{~d}$, respectively (Fig. 4a). The degradation rate of chlorophyll pigment depended on the long period of water deficit condition, causing chlorosis symptom prior to leaf senescence, especially older leaf position. In contrast, the maximum quantum yield of PSII $\left(\mathrm{F}_{\mathrm{v}} / \mathrm{F}_{\mathrm{m}}\right)$ and photon yield of PSII $\left(\Phi_{\text {PSII }}\right)$ in all treatments and at all the time periods were unchanged (Fig. $4 \mathrm{~b}$ and $4 \mathrm{c}$ ). In general, the $F_{v} / F_{m}$ and $\Phi_{\text {PSII }}$ were sensitive to water 
584

deficit, depending on plant species, genotypes, a degree of water deficit stress and their interaction. In present study, those parameters were retained relating to the highly efficient adaptation of cassava to water limitation. Interestingly, non-photochemical quenching (NPQ) in the water deficit stressed plants was significantly increased by 1.32 (150 DAP) and 1.90 folds (180 DAP) over wellirrigated plants (Fig. 4d), indicating the activity of anti- photooxidative generation.

At the harvesting stage (300 DAP), whole plant was manually collected and weighed separately as fresh storage root $\left(\mathrm{kg} \mathrm{plant}^{-1}\right)$ and the above ground biomass of stem and leaves (Fig. 5). Total above ground biomass, number of storage roots and storage root fresh weight in cassava grown under water shortage were significantly declined by $57.57 \%$, $18.18 \%$ and $30.41 \%$ to that of well-irrigated plants (Table 3 ).

Table 2. Number of leaves, leaf area index, plant height, and relative water content of cassava under WS and WW plots at 150 DAP. Value in parenthesis represents the \% reduction between WS and WW conditions

\begin{tabular}{ccccc}
\hline Water regime & $\begin{array}{c}\text { Number of leaves } \\
\left(\text { leaves plant }{ }^{-1}\right)\end{array}$ & $\begin{array}{c}\text { Leaf area index } \\
\left(\mathrm{m}^{2} \mathrm{~m}^{-2}\right)\end{array}$ & $\begin{array}{c}\text { Plant height } \\
(\mathrm{cm})\end{array}$ & $\begin{array}{c}\text { Relative water content } \\
(\%)\end{array}$ \\
\hline WW & $80 \pm 1.84 \mathrm{a}$ & $4.72 \pm 0.67 \mathrm{a}$ & $163 \pm 6.17 \mathrm{a}$ & $87.9 \pm 1.28 \mathrm{a}$ \\
WS & $74 \pm 2.78 \mathrm{~b}$ & $3.10 \pm 0.23 \mathrm{~b}$ & $138 \pm 2.43 \mathrm{~b}$ & $60.1 \pm 1.02 \mathrm{~b}$ \\
& $(7.50 \%)$ & $(34.32 \%)$ & $(15.34 \%)$ & $(31.63 \%)$ \\
& $*$-test & $*$ & $*$ & ${ }^{* *}$ \\
\hline
\end{tabular}

Data presented as mean $\pm \mathrm{SE}$ and different letters in a column represent significant difference at $\mathrm{p} \leq 0.05$. ns: not significant, ${ }^{*}:$ significant at $\mathrm{p} \leq 0.05,{ }^{* *}:$ highly significant at $\mathrm{p} \leq 0.01$ using $t$-test

Table 3. Total above ground biomass, number of storage roots and storage root fresh weight of cassava under WS and WW plots at the harvesting stage (300 DAP). Value in parenthesis represents the \% reduction between WS and WW conditions

\begin{tabular}{cccc}
\hline Water regime & $\begin{array}{c}\text { Total above ground biomass }(\mathrm{kg} \\
\left.\text { plant }^{-1}\right)\end{array}$ & $\begin{array}{c}\text { Number of storage root } \\
\left(\text { storage roots plant }^{-1}\right)\end{array}$ & $\begin{array}{c}\text { Storage root fresh weight } \\
\left(\mathrm{kg} \mathrm{plant}^{-1}\right)\end{array}$ \\
\hline WW & $3.70 \pm 1.40 \mathrm{a}$ & $11 \pm 0.58 \mathrm{a}$ & $4.44 \pm 0.13 \mathrm{a}$ \\
WS & $1.57 \pm 0.70 \mathrm{~b}$ & $9 \pm 0.33 \mathrm{~b}$ & $3.09 \pm 0.46 \mathrm{~b}$ \\
& $(57.57 \%)$ & $(18.18 \%)$ & $(30.41 \%)$ \\
& $*$-test & $* *$ & $*$ \\
\hline
\end{tabular}

Data presented as mean \pm SE and different letters in a column represent significant difference at $\mathrm{p} \leq 0.05$. ns: not significant, ${ }^{*}:$ significant at $\mathrm{p} \leq 0.05,{ }^{* *}:$ highly significant at $\mathrm{p} \leq 0.01$ using $t$-test
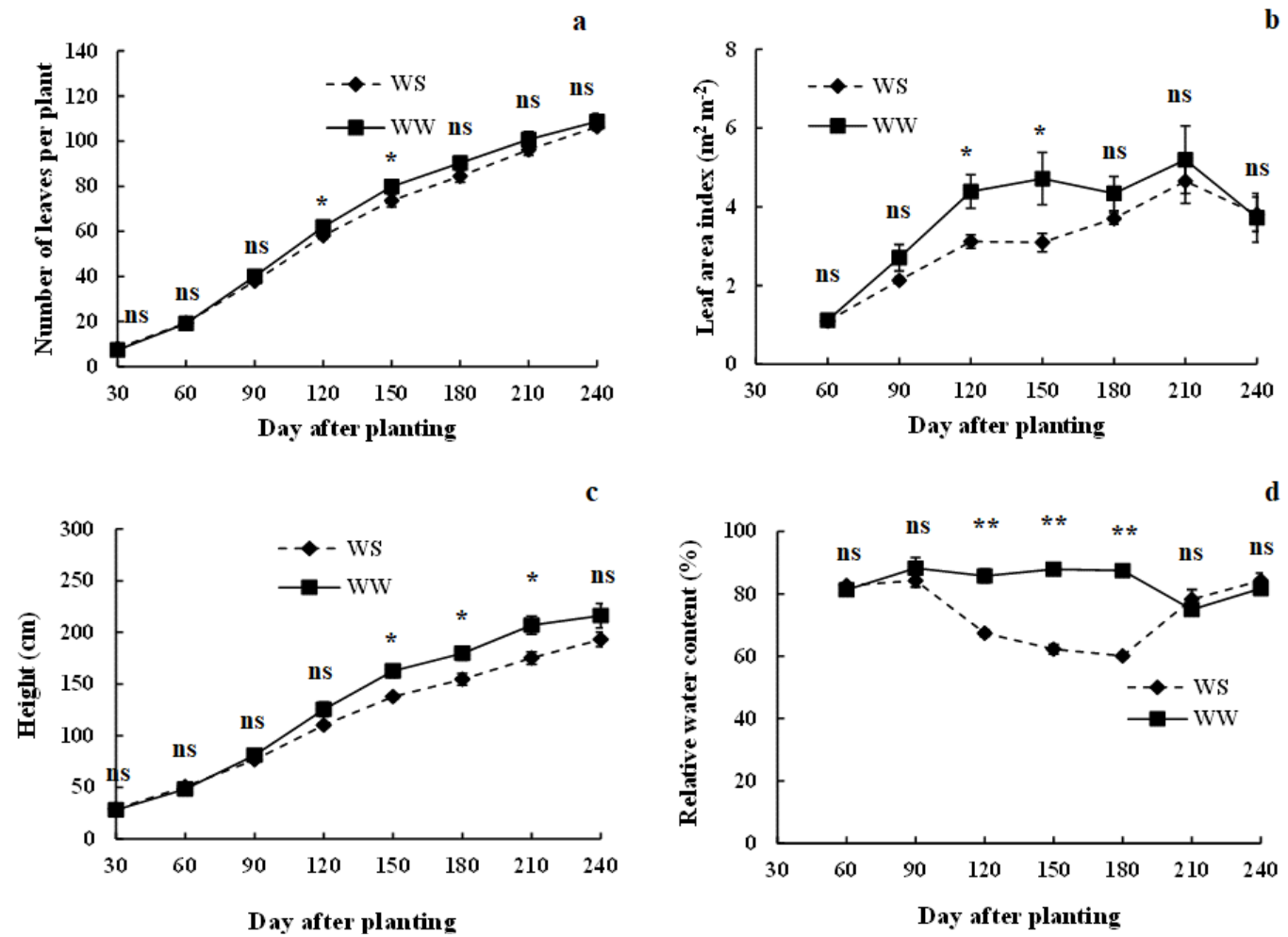

Fig. 3. Number of leaves per plant (a), leaf area index (b), plant height (c), and relative water content in the leaf tissues (d) of cassava grown in well-watered (WW) and water-stressed (WS) plots. Data presented as the mean of three replicates with standard error $( \pm S E)$, and different letters in a column represent significant difference at $p \leq 0.05$. ns: not significant, ${ }^{*}$ : significant at $p \leq$ $0.05,{ }^{* *}$ : highly significant at $\mathrm{p} \leq 0.01$ using $t$-test. 

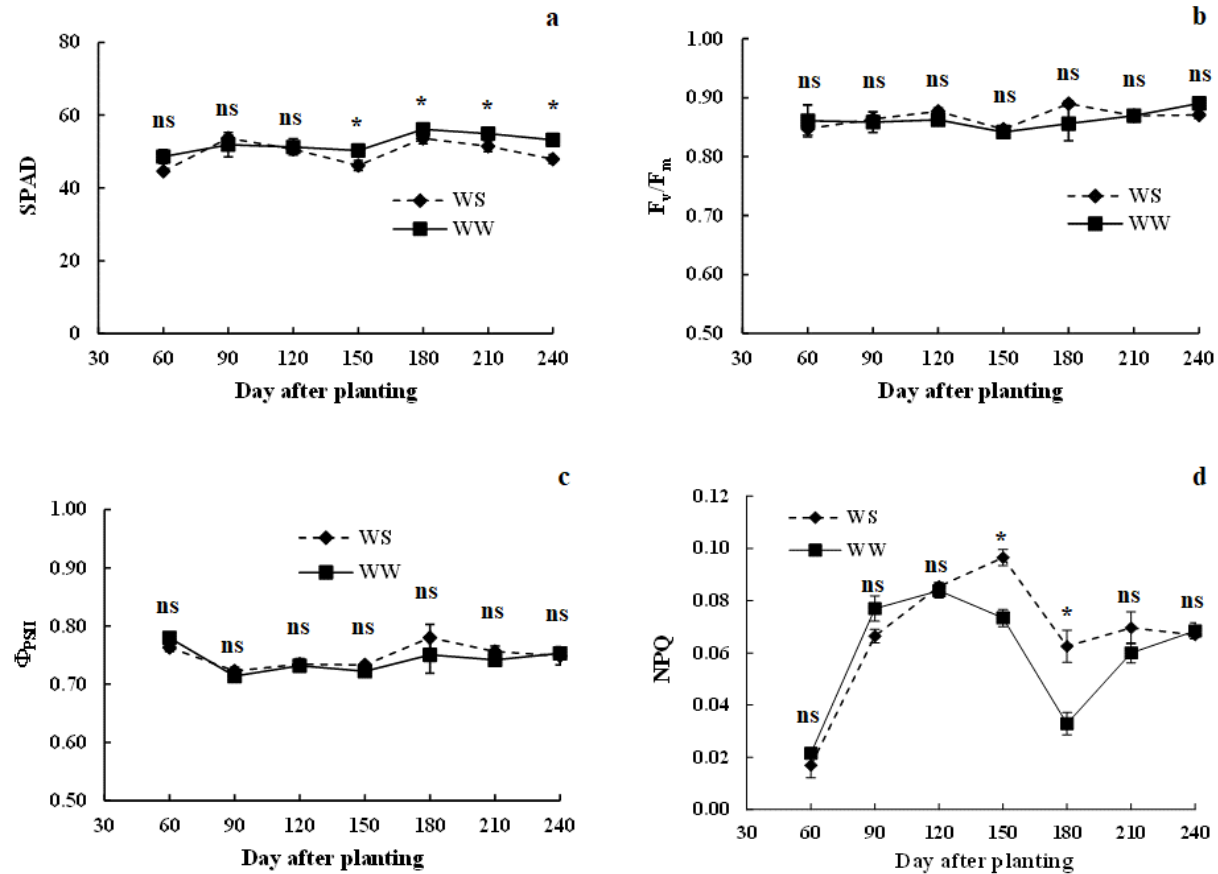

Fig. 4. Leaf greenness (SPAD; a), maximum quantum yield of PSII $\left(\mathrm{F}_{\mathrm{v}} / \mathrm{F}_{\mathrm{m}}\right)$; b), photo yield of PSII ( $\Phi_{\text {PSII }}$ c) and nonphotochemical quenching (NPQ: d) of cassava grown under well-watered (WW) and water-stressed (WS) plots. Data presented as the mean of three replicates with standard error $( \pm \mathrm{SE})$, and different letters in a column represent significant difference at $\mathrm{p} \leq$ 0.05. ns: not significant, ${ }^{*}$ : significant at $\mathrm{p} \leq 0.05$, using $t$-test

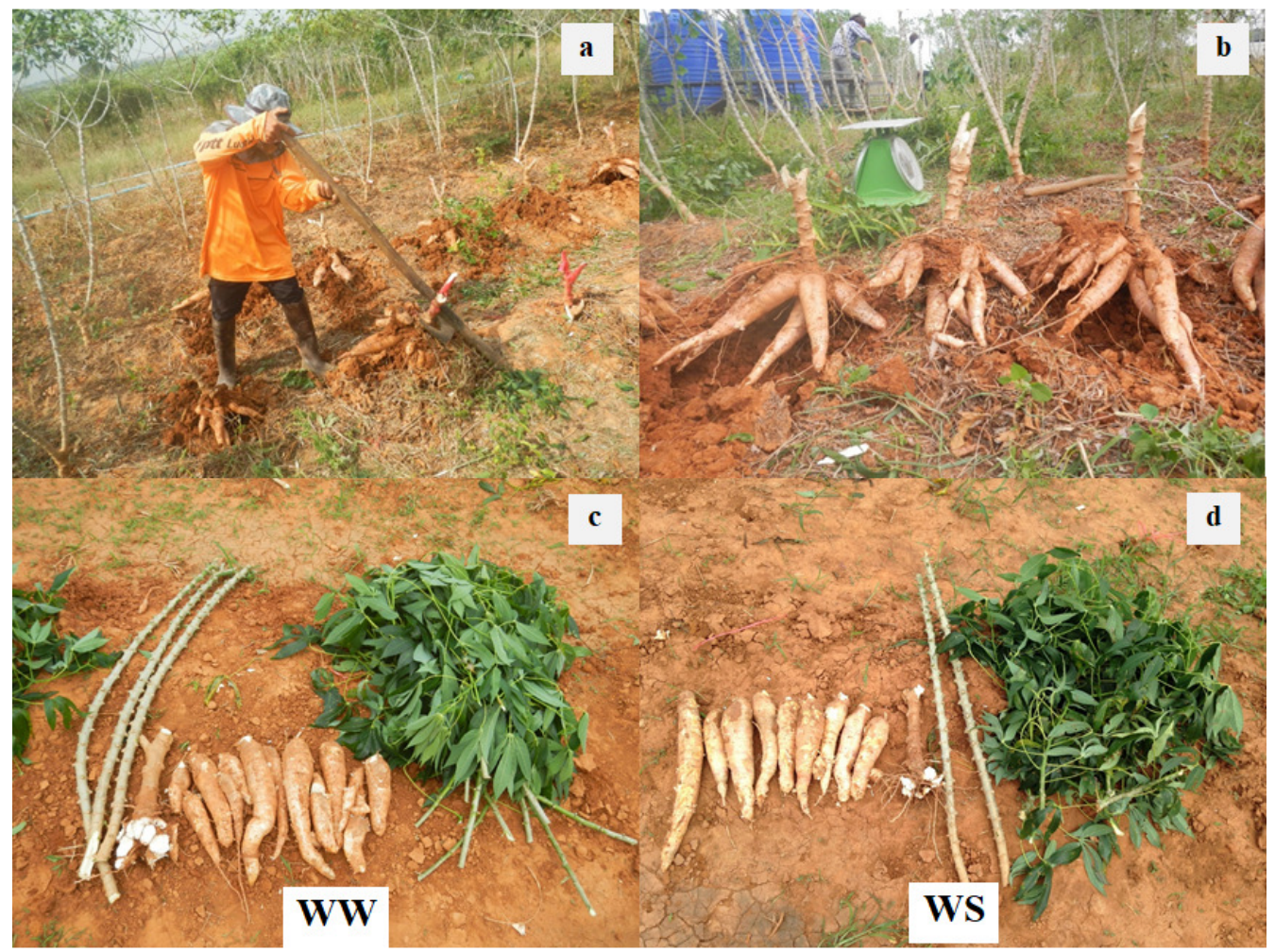

Fig. 5. Manually harvesting method of storage root (a), harvested storage root of cassava (b), the above ground biomass and storage root morphological characters of cassava grown under well-watered (WW) (c) and water-stressed (WS) plots (d) for 10 months (300 DAP) 
586

Vegetation indices to estimate leaf area index (LAI) in the water deficit condition

In the calibration model, LAI and VIs, non-destructive plant material methods under different water regimes were measured.

A significant difference of LAI at 120 and 150 DAP (after water withholding 90 and $120 \mathrm{~d}$ ), was demonstrated and the range of LAI of WS plot was found to be less than 4 $\mathrm{m}^{2} \mathrm{~m}^{-2}$ ground area whereas it was more than $4 \mathrm{~m}^{2} \mathrm{~m}^{-2}$ in WW plot (Fig. 3b). Maximum LAI under WS and WW plot was measured to be 4.65 and $5.20 \mathrm{~m}^{2} \mathrm{~m}^{-2}$, at $210 \mathrm{DAP}$, respectively. The LAI gradually increased during the early growth stage up to 210 DAP during the canopy development stage, and thereafter, declined until the storage root was fully developed at $240 \mathrm{DAP}$. In present study, the Visible Atmospherically Resistant Index (VARI) in water deficit stressed plants was declined at the early stage $[60 \mathrm{~d}$ water withholding] (27.7\% reduction of control) and $90 \mathrm{~d}$ (22.81\% reduction of control) water withholding period] (Table 4). In addition, the Ratio Vegetation Index (RVI) was found to be a good indicator, which showed a significant difference at 90 DAP $(19.33 \%$ reduction of control), 120 DAP (24.49\% reduction of control), 150 $\operatorname{DAP}(14.43 \%$ reduction of control) and $210 \mathrm{DAP}(21.26 \%$ reduction of control) under water deficit conditions, depending on a reduction of plant canopy adaptation. In contrast, Normalized Difference Vegetation Index (NDVI),
Enhanced Vegetation Index (EVI), Soil-adjusted Vegetation Index (SAVI) and Modified Second Triangular Vegetation Index (MTVI) models were insignificantly different between WW and WS using $t$-test (Table 4). The cassava LAI (Fig. 3b) and the six VIs (Table 1) showed highly positive exponential growth relationship and model equation (Table 5). The RVI and LAI showed the highest relationship under WS and WW plots with $\mathrm{R}^{2}=0.88$ and $\mathrm{R}^{2}=0.82$, respectively. The relationship between LAI and VIs of the cassava growth from 60 to 240 DAP was validated. The results showed that the RVI was obtained as the best index for estimating LAI under WS and WW plots with RMSE $=0.53$ and 0.64 , and $\mathrm{R}^{2}=0.89$ and 0.75 , respectively (Table 5).

Relationship between vegetation indices and yield attributes

At 90 and $120 \mathrm{~d}$ water withholding, the growth and physiological characters as well as LAI were significantly declined resulting in the reduction of final storage root yield. Based on this hypothesis, a positive relation between number of leaves and number of storage roots was demonstrated with $\mathrm{R}^{2}=0.99$ at 120 DAP (Fig. 6a) and $\mathrm{R}^{2}$ $=0.90$ at $150 \mathrm{DAP}$ (Fig. 6b). Moreover, a positive relation between LAI and storage root fresh weight was demonstrated with $\mathrm{R}^{2}=0.99$ at $120 \mathrm{DAP}$ (Fig. 6c) and $\mathrm{R}^{2}$ $=0.92$ at $150 \mathrm{DAP}$ (Fig. 6d).

Table 4. Calibrated data set of cassava LAI and VIs under different water regimes. Value in parenthesis represents the \% reduction between WS and WW conditions

\begin{tabular}{|c|c|c|c|c|c|c|c|}
\hline \multirow[t]{2}{*}{ Treatment } & \multicolumn{7}{|c|}{ Day after planting } \\
\hline & 60 & 90 & 120 & 150 & 180 & 210 & 240 \\
\hline \multicolumn{8}{|c|}{ NDVI } \\
\hline WW & $0.69 \pm 0.01$ & $0.91 \pm 0.00$ & $0.92 \pm 0.00$ & $0.92 \pm 0.00$ & $0.92 \pm 0.01$ & $0.91 \pm 0.01$ & $0.90 \pm 0.01$ \\
\hline WS & $0.67 \pm 0.05$ & $0.89 \pm 0.01$ & $0.90 \pm 0.01$ & $0.91 \pm 0.01$ & $0.92 \pm 0.00$ & $0.93 \pm 0.00$ & $0.92 \pm 0.00$ \\
\hline$t$-test & ns & ns & $\mathrm{ns}$ & ns & ns & ns & ns \\
\hline \multicolumn{8}{|l|}{ RVI } \\
\hline WW & $5.39 \pm 0.15$ & $21.00 \pm 0.12$ & $25.68 \pm 0.69 a$ & $25.01 \pm 1.22 \mathrm{a}$ & $24.55 \pm 2.30$ & $27.19 \pm 0.80 \mathrm{a}$ & $20.24 \pm 2.19$ \\
\hline WS & $5.39 \pm 0.94$ & $\begin{array}{c}16.94 \pm 0.93 \\
(19.33 \%)\end{array}$ & $\begin{array}{c}19.39 \pm 2.24 \mathrm{~b} \\
(24.49 \%)\end{array}$ & $\begin{array}{c}21.40 \pm 1.45 b \\
(14.43 \%)\end{array}$ & $25.02 \pm 1.47$ & $\begin{array}{c}21.41 \pm 1.43 b \\
(21.26 \%)\end{array}$ & $23.20 \pm 0.77$ \\
\hline$t$-test & ns & * & * & $*$ & ns & * & ns \\
\hline \multicolumn{8}{|l|}{ EVI } \\
\hline WW & $0.52 \pm 0.01$ & $0.83 \pm 0.01$ & $0.96 \pm 0.02$ & $1.00 \pm 0.01$ & $0.98 \pm 0.02$ & $0.91 \pm 0.01$ & $0.87 \pm 0.03$ \\
\hline WS & $0.49 \pm 0.06$ & $0.81 \pm 0.02$ & $0.97 \pm 0.02$ & $1.00 \pm 0.01$ & $0.92 \pm 0.04$ & $0.89 \pm 0.04$ & $0.93 \pm 0.04$ \\
\hline$t$-test & ns & ns & ns & ns & ns & ns & ns \\
\hline \multicolumn{8}{|l|}{ SAVI } \\
\hline WW & $0.51 \pm 0.01$ & $0.71 \pm 0.01$ & $0.79 \pm 0.01$ & $0.81 \pm 0.01$ & $0.80 \pm 0.01$ & $0.76 \pm 0.01$ & $0.74 \pm 0.02$ \\
\hline WS & $0.48 \pm 0.05$ & $0.70 \pm 0.01$ & $0.80 \pm 0.01$ & $0.81 \pm 0.01$ & $0.77 \pm 0.02$ & $0.75 \pm 0.03$ & $0.77 \pm 0.02$ \\
\hline$t$-test & ns & ns & ns & ns & ns & ns & ns \\
\hline \multicolumn{8}{|l|}{ VARI } \\
\hline WW & NA & $0.55 \pm 0.02 \mathrm{a}$ & $0.57 \pm 0.01 \mathrm{a}$ & $0.53 \pm 0.04$ & $0.57 \pm 0.01$ & $0.56 \pm 0.03$ & $0.53 \pm 0.03$ \\
\hline WS & NA & $\begin{array}{c}0.40 \pm 0.02 b \\
(27.27 \%)\end{array}$ & $\begin{array}{c}0.44 \pm 0.04 b \\
(22.81 \%)\end{array}$ & $0.50 \pm 0.01$ & $0.54 \pm 0.03$ & $0.56 \pm 0.01$ & $0.56 \pm 0.02$ \\
\hline$t$-test & - & $* *$ & * & ns & ns & ns & ns \\
\hline \multicolumn{8}{|l|}{ MTVI2 } \\
\hline WW & $0.45 \pm 0.00$ & $0.83 \pm 0.01 \mathrm{a}$ & $0.91 \pm 0.01$ & $0.92 \pm 0.01$ & $0.92 \pm 0.01$ & $0.88 \pm 0.01$ & $0.85 \pm 0.03$ \\
\hline WS & $0.42 \pm 0.06$ & $0.78 \pm 0.01 b$ & $0.88 \pm 0.02$ & $0.90 \pm 0.01$ & $0.89 \pm 0.02$ & $0.88 \pm 0.02$ & $0.89 \pm 0.02$ \\
\hline$t$-test & ns & ns & ns & ns & ns & ns & ns \\
\hline
\end{tabular}

highly significant at $\mathrm{p} \leq 0.01$ using $t$-test. 
Table 5. Calibrated and validated values of cassava VIs for estimated LAI under different water regimes

\begin{tabular}{|c|c|c|c|c|c|}
\hline \multirow{2}{*}{ Water regime } & \multirow{2}{*}{ Input variable } & \multicolumn{2}{|c|}{ Calibrated $(n=21)$} & \multicolumn{2}{|c|}{ Validated $(\mathrm{n}=21)$} \\
\hline & & Model equation & $\mathrm{R}^{2}$ & RMSE & $\mathrm{R}^{2}$ \\
\hline \multirow[t]{6}{*}{ WW } & NDVI & $y=0.0194 e^{5.8363 x}$ & 0.80 & 0.75 & 0.66 \\
\hline & RVI & $y=0.7944 e^{0.0702 x}$ & 0.82 & 0.64 & 0.75 \\
\hline & EVI & $y=0.2322 e^{3.0767 x}$ & 0.82 & 3.03 & 0.04 \\
\hline & SAVI & $y=0.1000 e^{4.7948 x}$ & 0.82 & 0.77 & 0.71 \\
\hline & VARI & $y=1.2159 e^{2.1654 x}$ & 0.76 & 2.68 & 0.66 \\
\hline & MTVI2 & $y=0.2753 e^{3.0378 x}$ & 0.83 & 2.86 & 0.80 \\
\hline \multirow[t]{6}{*}{ WS } & NDVI & $y=0.0607 e^{4.3747 x}$ & 0.71 & 0.76 & 0.72 \\
\hline & RVI & $y=0.8193 e^{0.0623 x}$ & 0.88 & 0.53 & 0.89 \\
\hline & EVI & $y=0.3960 e^{2.2868 x}$ & 0.69 & 2.76 & 0.12 \\
\hline & SAVI & $y=0.2218 e^{3.4948 x}$ & 0.69 & 0.80 & 0.66 \\
\hline & VARI & $y=0.7802 e^{2.8909 x}$ & 0.85 & 2.19 & 0.54 \\
\hline & MTVI2 & $y=0.3919 e^{2.4416 x}$ & 0.78 & 1.25 & 0.72 \\
\hline
\end{tabular}

a

b
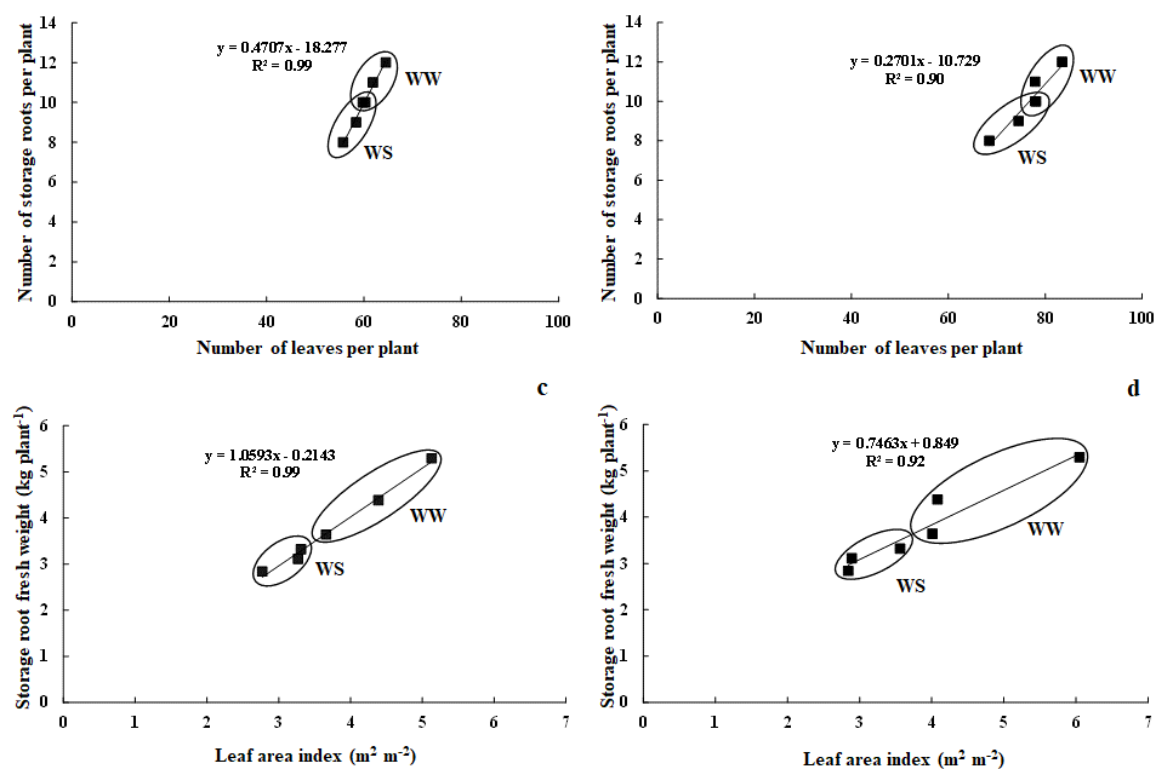

Fig. 6. Relationships between number of leaves per plant (120 DAP) and number of storage roots per plant (a), number of leaves per plant (150 DAP) and number of storage roots per plant (b), leaf area index (120 DAP) and storage root fresh weight (c) as well as leaf area index (150 DAP) and fresh storage root weight (d) of cassava grown under well-watered (WW) and waterstressed (WS) plots

\section{Discussion}

Leaf expansion (size), leaf retention, number of leaves and delayed senescence in cassava are directly related to growth and storage root yield, especially under the drought conditions (Alves and Setter, 2004; Turyagyenda et al., 2013; Liao et al., 2017). Number of new leaves and rate of plant height ( $\mathrm{cm} \mathrm{day}^{-1}$ ) of cassava cv. C-1 under water deficit stress are significantly declined when compared with those in well-irrigated plants (Duque and Setter, 2013). In cassava cv. 'CM 1585-13', fallen leaves are evidently observed in the water deficit stressed plants and the emerged leaves are limited, leading to small leaf area and delayed shoot elongation (reduced height) when compared with control (well watering) (Calatayud et al., 2000). Leaf area and rate of leaf expansion in cassava grown under water stress was significantly dropped ( $>50 \%$ reduction of control) within 6 $\mathrm{d}$ of water withholding and then quickly recovered in the rewatering process for $3 \mathrm{~d}$ (Alves and Setter, 2000). In addition, LAI is a key factor to regulate storage root yield of cassava (El-Sharkawy, 2007). Leaf relative water content in cassava cv. IAC 576-70 significantly declined depending on the days of water deficit stress especially after $90 \mathrm{~d}$ water withholding period (Pereira et al., 2018) and genotypic dependence factor; for example, cv. 'Nyalanda' is sensitive to $10 \mathrm{~d}$ moisture stress (Turyagyenda et al., 2013).

Total chlorophyll content in the leaf tissues of water deficit stressed cassava cv. IAC 576-70 were maintained after water deficit treatments, leading to a constant maximum quantum yield of PSII $\left(\mathrm{F}_{\mathrm{v}} / \mathrm{F}_{\mathrm{m}}\right)$ (Pereira et al., 2018). In contrast, $F_{v} / F_{m}$ in cassava cv. SC 5 was significantly 
588

declined when exposed to water deficit for the long period ( $\geq$ 6d water withholding) (Liao et al., 2016; Liao et al., 2017). Reduction rate of $F_{v} / F_{m}$ in cassava grown under water deficit stress was genotype-dependent; for example, $\mathrm{F}_{\mathrm{v}} / \mathrm{F}_{\mathrm{m}}$ in $\mathrm{cv}$. SC124 was more sensitive to water stress than that in cv. Arg7 (Zhao et al., 2015). In cassava cv. 'Cigana Preta', $\mathrm{F}_{\mathrm{v}} / \mathrm{F}_{\mathrm{m}}$ in plants under nitrogen deficiency was maintained, whereas photon yield of PSII ( $\left.\Phi_{\text {PSII }}\right)$ was diminished. On the other hand, non-photochemical quenching (NPQ) in nitrogen deficient plants was enhanced (Cruz et al., 2003). Under cold stress $\left(5^{\circ} \mathrm{C}\right.$ for 10 d), $F_{v} / F_{m}$ and $\Phi$ PsII in two cultivars, SC8 and Col 1046 were significantly diminished, while NPQ was increased (An et al., 2016). In general, NPQ in the water deficit stressed plants was promoted with the high electron transport rate, which generates the heat toxicity at cellular levels (Chaves et al., 2002; Liu et al., 2008; Dahal and Vanlerberghe, 2018).

Biomass, number of storage roots and storage root yield per plant in cassava were sensitive to water deficit conditions (Adjebeng-Danquah et al., 2016 b; 2016c). In addition, the yield attributes of cassava under water shortage was genotype-dependent and can be rapidly recovered under rewatering process or precipitation (El-Sharkawy, 2007; Vandegeer et al., 2013). The planting date schedule relating to water shortage in weather forecasting is one of major factor to be concerned for cassava production using LINTUR model (Ezui et al., 2018).

The precipitation in the field directly affected the soil moisture in the WS and WW plots, and slightly different in the late growth stage. However, parameters in the early stage of cassava at 120 to 150 DAP ( 90 to $120 \mathrm{~d}$ water withholding) showed sensitivity to water deficit stress. The optimal LAI for storage root bulking was reported to be 3.0 to $3.5 \mathrm{~m}^{2} \mathrm{~m}^{-2}$ (Hillock et al., 2001), and the LAI for starch formation as reported in Thailand is $4.0 \mathrm{~m}^{2} \mathrm{~m}^{-2}$ (Boonseng, 2008). The number of leaves, leaf retention, and expanded size of leaves is peaked at 4 to 6 months after planting (MAP) and then leaf size and rate of leaf production are decreased at senescence (Ekanayake et al., 1998). Under water deficit stress, LAI was slightly reduced depending on the tolerant ability or genotype-dependent strategies to maintain the storage root yield (El-Sharkawy, 2004). Furthermore, this research demonstrated that LAI is a good indicator for overall growth performances and yield prediction in cassava. Therefore, storage root yield is declined when LAI exceeded $\left(>4 \mathrm{~m}^{2} \mathrm{~m}^{-2}\right)$, due to less carbohydrate assimilates in the storage roots (Ekanayake et al., 1998). Moreover, non-destructive vegetation models were validated. RVI was highly related to LAI of the cassava under different water regimes and can be applied to estimate LAI of cassava. The RVI to estimate over-story LAI, and normalized forms to the NDVI for reducing the impact of atmospheric scattering are good predictors of wet and dry green biomass, LAI and fractional cover (Thenkabail et al., 2012).

In cassava, a positive relationship between number of leaves per plant and number of storage roots in cassava genotypes has been demonstrated $\left(\mathrm{R}^{2}=0.44 ; \mathrm{p} \leq 0.001\right)$ in the Guinea Savannah Ecology of Ghana (AdjebengDanquah et al., 2016a). Moreover, positive relation between number of leaves per plant and number of storage roots in cassava cv. MCol 1468 is validated with $R^{2}=0.87$ (Vandegeer et al., 2013). Storage root numbers in cassava are closely related with number of leaves $\left(\mathrm{R}^{2}=0.49 ; \mathrm{p} \leq\right.$ 0.001) (Ntawuruhunga et al., 2001). In contrast, independence between number of leaves and number of storage roots per plant was reported in both high cyanide cassava $\left(\mathrm{R}^{2}=0.22^{\mathrm{ns}}\right)$ and low cyanide cassava $\left(\mathrm{R}^{2}=0.40^{\mathrm{ns}}\right)$ in acid Ultisols of Southern Nigeria (Okpara et al., 2014a) as well as high cyanide cassava $\left(\mathrm{R}^{2}=0.22^{\mathrm{ns}}\right)$ and low cyanide cassava $\left(\mathrm{R}^{2}=0.34^{\mathrm{ns}}\right)$ in the humid tropics (Okpara et al., 2014b). In the water deficit stress, number of leaves in 20 elite clones of cassava was thoroughly related with the storage root yield $\left(\mathrm{R}^{2}=0.45 ; \mathrm{p} \leq 0.001\right)$ (AdjebengDanquah et al., 2016b). For the yield traits, a positive relation between LAI and storage root yield has been widely established in cassava crop in Midwestern Nigeria $\left(\mathrm{R}^{2}=\right.$ 0.71; $\mathrm{p} \leq$ 0.01; Odjugo, 2008), in tall- and short-stemmed rain-fed cassava cultivars $\left(\mathrm{R}^{2}=0.42 ; \mathrm{p} \leq 0.01\right.$; El-Sharkawy and de Tafur, 2010) and in 30 elite clones of cassava $\left(R^{2}=\right.$ 0.42; p $\leq$ 0.001; El-Sharkawy et al., 2012). Recently, storage root yield in 20 cultivars of cassava grown under no irrigation increased in relation to the long harvesting times (12 MAP) (Adjebeng-Danquah et al., 2016c).

\section{Conclusions}

Number of leaves and the LAI in cassava cv. 'Huay Bong $80^{\prime}$ are good indicators to predict overall growth and storage root yield. Chlorophyll degradation and relative water content reduction in the leaf tissues are the key physiological indices in water shortage conditions of cassava. For nondestructive measurement model, the LAI as RVI should be applied to estimate cassava growth, biomass and storage root yield under water deficit conditions. The critical point at 150 DAP (120 d water withholding), the storage root bulking stage of cassava, is an indicator to growth development and yield performance of cassava. The LAI at 150 DAP was observed to estimate the storage root yield. The future LAI work may be validated under different environments and several dominating cassava cultivars within local genotypes. New remote sensing technologies, including very high spatial data, unmanned air vehicle and micro-hyperspectral imagery may further be applied in farmer field trials.

\section{Acknowledgements}

The authors would like to thank the Thai Tapioca Development Institute (TTDI), Nakhon Ratchasima province, Thailand, for the field trial validation. This research was supported by the National Research Council of Thailand (NRCT), the Cluster and Program Management Office (CPMO funding number P-1300634) of the National Science and Technology Development Agency (NSTDA). 


\section{References}

Adjebeng-Danquah J, Gracen VE, Offei SK, Asante IK, Manu-Advening J (2016a). Agronomic performance and genotypic diversity for morphological traits among cassava genotypes in the Guinea Savannah Ecology of Ghana. Journal of Crop Science and Biotechnology 19(1):99-108.

Adjebeng-Danquah J, Manu-Advening J, Gracen VE, Offei SK, Asante IK (2016b). Genotypic variation in abscisic acid content, carbon isotope ratio and their relationship with cassava growth and yield under moisture stress and irrigation. Journal of Crop Science and Biotechnology 19(4):263-273.

Adjebeng-Danquah J, Gracen VE, Offei SK, Asante IK, Manu-Advening J (2016c). Genetic variability in storage root bulking of cassava genotypes under irrigation and no irrigation. Agriculture and Food Security 5(1):9.

Alves AAC, Setter TL (2000). Response of cassava to water deficit: Leaf area growth and abscisic acid. Crop Science 40(1):131-137.

Alves AAC, Setter TL (2004). Response of cassava leaf area expansion to water deficit: Cell proliferation, cell expansion and delayed development. Annals of Botany 94(4):605-613.

An F, Li G, Li QX, Li K, Carvalho LJCB, Ou W, Chen S (2016). The comparatively proteomic analysis in response to cold stress in cassava plantlets. Plant Molecular Biology Reports 34(6):1095-1110.

Bakhshandeh E, Kamkar B, Tsialtas JT (2011). Application of linear models for estimation of leaf area in soybean [Glycine max (L.) Merr]. Photosynthetica 49(3):405-416.

Boonseng $\mathrm{O}$ (2008). How does the planting for high yield of cassava. Accessed: November 2016. http://www.tapiocathai.org/Articles/ 51_8.pdf.

Boonyanuphap J (2014). Principle of remote sensing for vegetation ecology and conversation. Odeonstore: Bangkok.

Calatayud PA, Llovera E, Bois JF, Lamaze T (2000). Photosynthesis in drought-adapted cassava. Photosynthetica 38(1):97-104.

Cemek B, Unlukara A, Kurunc A (2011). Nondestructive leaf-area estimation and validation for green pepper (Capsicum annum L.) grown under different stress conditions. Photosynthetica 49(1):98-106.

Chaves MM, Pereira JS, Maroco J, Rodrigues ML, Ricardo CPP, Osório ML, ... Pinheiro C (2002). How plants cope with water stress in the field. Photosynthesis and growth. Annals of Botany 89(7):907-916.

CockJH, Franklin D, Sandoval G, Juri P (1979a). The ideal cassava plant for maximum yield. Crop Science 19(2):271-279.

Cock JH, Joseph KJ, Ramli K (1979b). Influence of soil applied micronutrients on cassava (Manihot esculenta) in Malaysian tropical oligotrophic peat. Experimental Agriculture 14(2):105-111.

Crisrofori V, Rouphael Y, Gyves EM, Bignami C (2007). A simple model for estimating leaf area of hazelnut from linear measurements. Scientia Horticulturae 113(2):221-225.

Cruz JL, Mosquim PR, Palacani CR, Araújo WL, DaMatta FM (2003). Photosynthesis impairment in cassava leaves in response to nitrogen deficiency.Plant and Soil 257(2):417-423.

Dahal K, Vanlerberghe GC (2018). Improved chloroplast energy balance during water deficit enhances plant growth: more crop per drop. Journal ofExperimental Botany 69(5):1183-1197.
DaryantoS, WangL,Jacinthe PA (2017). Global synthesis of drought effects on cereal, legume, tuber and root crops production: A review. Agricultural Water Management 179:18-33.

Duque LO, Setter TL (2013). Cassava response to water deficit in deep pots: Root and shoot growth, $\mathrm{ABA}$, and carbohydrate reserves in stems, leaves and storage root. Tropical Plant Biology 6(4):119-209.

Ekanayake IJ, Osiru DSO, Porto MCM (1998). Physiology of cassava. International Institute of Tropical Agriculture.

El-Sharkawy MA (2004). Cassava biology and physiology. Plant Molecular Biology 56(5):481-501.

El-Sharkawy MA (2007). Physiological characteristics of cassava tolerance to prolonged drought in the tropics: Implications for breeding cultivars adapted to seasonally dry and semiarid environments. Brazilian Journal of Plant Physiology 19(4):257-286.

El-Sharkawy MA, de Tafur SM (2010). Comparative photosynthesis, growth, productivity and nutrient use efficiency among tall- and shortstemmed rain-fed cassava cultivars. Photosynthetica 48(2):173-188.

El-Sharkawy MA, de Tafur SM, Lopez Y (2012). Eco-physiological research for breeding improved cassava cultivars in favorable and stressful environments in tropical/subtropical bio-systems. Environmental Research Journal 6:143-211.

Ezui KS, Leffelaar PA, Franke AC, Mando A, Giller KE (2018). Simulating drought impact and mitigation in cassava using the LINTUL model. Field Crops Research 219:256-272.

Fakir MSA, Mostafa MG, Karim MR, Prodhan AKMA (2011).Prediction of leaf number by linear regression models in cassava. Journal of Bangladesh Agriculture University 9(1):49-54.

Gitelson AA, Kaufman YJ, Stark R, Rundquist D (2002). Novel algorithms for remote estimation of vegetation fraction. Remote Sensing of Environment 80(1):76-87.

Gyves EM, Rouphael Y, Crisrofori V, Mira FR (2007). A non-destructive, simple and accurate model for estimating the individual leaf area of kiwi (Actinidia deliciosa). Fruits 62(3):171-176.

Haboudane D, Miller JR, Pattey E, Zarco-Tejada PJ, Strachan I (2004). Hyperspectral vegetation indices and novel algorithms for predicting green LAI of crop canopies: modeling and validation in the context of precision agriculture. Remote Sensing of Environment 90(3):337-352.

Hillock RJ, Thresh JM, Bellotti AC (2001). Cassava: biology, production, and utilization. CABI Publishing: USA.

Hossain S, Wang L, Chen T, Li Z (2017). Leaf area index assessment for tomato and cucumber growing period under different water treatments. Plant, Soil andEnvironment 63(10):461-467.

Huete AR (1988). A soil-adjusted vegetation index (SAVI). Remote Sensing ofEnvironment 25(3):295-309.

Huete AR, Didan K, Miura T, Rodriguea EP, Gao X, Ferreira LG (2002). Overview of the radiometric and biophysical performance of the MODIS vegetation indices. Remote Sensing of Environment 83(12):195-213.

Itani J, Oda T, Numao T (1999). Studies on mechanisms of dehydration postponement in cassava leaves under short-term soil water deficit. Plant Production Science 2(3):184-189.

Jansson C, Westerbergh A, Zhang J, Hu X, Sun C (2009). Cassava, a potential biofuel crop in (the) People's Republic of China. Applied 
590

\section{Energy 86:S95-S99.}

Jonckheere I, Fleck S, Nackaerts K, Muysa B, Coppin P, Weiss M, Baret F (2004). Review of methods for in situ leaf area index determination Part I. Theories, sensors and hemispherical photography. Agricultural and Forest Meteorology 121(1-2):19-35.

Jone HG, Vaughan RA (2010). Remote sensing of vegetation. Oxford University Press: New York.

Jordan CF (1969). Leaf-area index from quality of light on the forest floor. Ecology 50(4):663-666.

Jose LZ, Whiting ML, Lampinen BD, Metcalf S, Ustin SL, Brown PH (2012). Prediction of leaf area index in almonds by vegetation indexes. Computers and Electronics Agriculture 85:2432.

Keramatlou I, Sharifani M, Sabouri H, Alizadeh M, Kamkar B (2015). A simple linear model for leaf area estimation in Persian walnut (Juglans regia L.).Scientia Horticulturae 184:36-39.

Lenis JI, Calle F, Jaramillo G, Perez JC, Ceballos H, Cock JH (2006). Leaf retention and cassava productivity. Field Crops Research 95(2-3):126134.

Lioa W, Wang G, Li Y, WangB, ZhangP, Peng M (2016). Reactive oxygen species regulate leaf pulvinus abscission zone cell separation in response to water-deficit stress in cassava. Scientific Reports 6:21542.

Liao WB, Li YY, Lu C, Peng M (2017). Expression of sucrose metabolism and transport genes in cassava petiole abscission zones in response to water stress. Biologia Plantarum 61(2):219-226.

Liu Y, Zhang T, Wang J (2008). Photosynthesis and metabolite levels in dehydratingleaves of Reaumuria soongorica. Acta Biologica Cracoviensia Series Botanica 50(1):19-26.

Loggini B, Scartazza A, Brugnoli E, Navari-Izzo F (1999). Antioxidant defense system, pigment composition, and photosynthetic efficiency in two wheat cultivars subjected to drought. Plant Physiology 119(3):1091-1100.

Maxwell K, Johnson GN (2000). Chlorophyll fluorescence-a practical guide. Journal of Experimental Botany 51(345):659-668.

Nguyen TL, Gheewala SH, Garivait S (2007). Full chain energy analysis of fuel ethanol from cassava in Thailand. Environmental Science and Technology 41(11):4135-4142.

Ntawuruhunga P, Rubaihayo PR, Whyte JBT, Dixon AGO, Osiru DSO (2001). Inter-relationships among traits and path analysis for yield components of cassava: A research for storage root yield indicators. African CropScience Journal 9(4):599-606.

Nuwamanya E, Chiwona-Karltun L, Kawuki RS, Baguma Y (2012). Bioethanol production from non-food parts of cassava (Manihot esculenta Crantz).Ambio 41(3):262-270.

Odjugo PAO (2008). The impact of tillage systems on soil microclimate, growth and yield of cassava (Manihot esculenta Crantz) in Midwestern Nigeria. African Journal of Agricultural Research 3(3):225-233.

Oguntunde PG (2005). Whole-plant water use and canopy conductance of cassava under limited available soil water and varying evaporative demand. Plant and Soil 278(1-2):371-383.

Okogbenin E, Setter TL, Ferguson M, Mutegi R, Ceballos H, Olasanmi B, Fregene M (2013). Phenotypic approaches to drought in cassava: Review. Frontiers in Plant Science 4:93.

Okpara DA, Mbah EU, Chukwu EI (2014a). Assessment of growth and yield of some high- and low-cyanide cassava genotypes in acid Ultisols of Southeastern Nigeria. African Journal of Biotechnology 13(5):651-656.

Okpara DA, Mbah EU, Ojikpong TO (2014b). Associate and part coefficients analysis of fresh root yield of high and low cyanide cassava (Manihot esculenta Crantz) genotypes in the humid tropics. Journal of CropScience and Biotechnology 17(2):103-109.

Pardales JR, Esquibel CB (1996). Effect of drought during the establishment period on the root system development of cassava. Japan Journal of CropScience 65(1):93-97.

Pask A, Pietragalla J, Mullan D, Reynolds M (2012). Physiological breeding II: A field guide to wheat phenotyping. International Maize and Wheat Improvement Center.

Peksen E (2007). Non-destructive leaf area estimation model for faba bean (Viciafaba L.).Scientia Horticulturae 113(4):322-328.

Peper PJ, McPherson EG (1998). Comparison of five methods for estimating leaf area index of open grown deciduous trees. Journal of Arboriculture 24:98-111.

Pereira LFM, Zanetti S, Silva MA (2018). Water relations of cassava cultivated under water-deficit levels. Acta Physiologiae Plantarum 40:13.

PompelliMF, Antunes WC, Ferreira DTRG, Cavalcante PGS, WanderleyFilho HCL, Endres L (2012). Allometric models for non-destructive leafarea estimation of Jatropha curcas. Biomass and Bioenergy 36:77-85.

Reynolds M, Pask A, Mullan D (2011). Physiological breeding I: Interdisciplinary approaches to improve crop adaptation. International Maize and Wheat Improvement Center.

Rouse JW, Haas RH, Schell JA, Deering DW, Harlan JC (1974). Monitoring the vernal advancement and retrogradation (greenwave effect) of natural vegetation. Greenbelt, MD: USA.

Sala F, Arsene GG, Iordănescu O, Boldea M (2015). Leaf area constant model in optimizing foliar area measurement in plants: A case study in apple tree. Scientia Horticulturae 193:218-224.

Thenkabail PS, Lyon JG, Huete A (2012). Hyperspectral remote sensing of vegetation. CRC Press.

Tondjo K, Brancheriau L, Sabatier SA, Kokutse AD, Akossou A, Kokou K, Fourcaud T (2015). Non-destructive measurement of leaf area and dry biomass in Tectona grandis. Trees 29(5):1625-1631.

Turyagyenda LF, Kizito EB, Ferguson M, Baguma Y, Agaba M, Harvey JJW, Osiru DSO (2013). Physiological and molecular characterization of drought responses and identification of candidate tolerance genes in cassava. AoB Plants 5:plt007.

Uddling J, Gelang-Alfredsson J, Piikki K, Pleijel H (2007). Evaluating the relationship between leaf chlorophyll concentration and SPAD-502 chlorophyll meter reading. Photosynthesis Research 91(1):37-46.

Vandegeer R, Miller RE, Bain M, Gleadow RM, Cavagnaro TR (2013). Drought adversely affects tuber development and nutritional quality of the staple crop cassava (Manihot esculenta Crantz). Functional Plant Biology 40(2):195-200.

Vichukit V, Rodjanaridpiched C, Sarobol E, Jeamjamnanja J, Siroth K, Piyachomkwan K, Leartmongkol W, Kittipadakul P, Chanthaworn J, Boonma S (2011). Huay Bong 80: Thailand's first cassava variety registered as a new protected variety. Agricultural Science Journal 42:349-358.

Vijendra KB, ChandraS (2012). Estimating leaf area index for an arid region 
using spectral data. African Crop Science Journal 20(4):215-223.

Welles JM (1990). Some indirect methods of estimating canopy structure. RemoteSensing Reviews 5(1):31-43.

Wiersma JV, Bailey TB (1975). Estimation of leaflet, trifoliate and total leaf area of soybean. Agronomy Journal 6(7):26-30.

Xavier AC, Vettorazzi CA (2004). Mapping leaf area index through spectral vegetation indices in a subtropical watershed. International Journal of RemoteSensing 25(9):1661-1672.

Xiao X,He L, Salas W,Li C, Moore B, Zhao R, FrolokingS, Boles S (2012). Quantitative relationships between field-measured leaf area index and vegetation index derived from VEGETATION images for paddy rice fields. International Journal of Remote Sensing 23(18):3595-3604.
Zhao P, Liu P, Shao J, LiC, Wang B, Guo X, Yan B, Xia Y, Peng M(2015). Analysis of different strategies adapted by two cassava cultivars in response to drought stress: ensuring survival or continuing growth. Journal of Experimental Botany 66(5):1477-1488.

Ziska LH, Runion GB, Tomecek M, Prior SA, Torbert HA, Sicher R (2009). An evaluation of cassava, sweet potato and field corn as potential carbohydrate sources for bioethanol production in Alabama and Maryland. Biomass and Bioenergy33(11):1503-1508. 

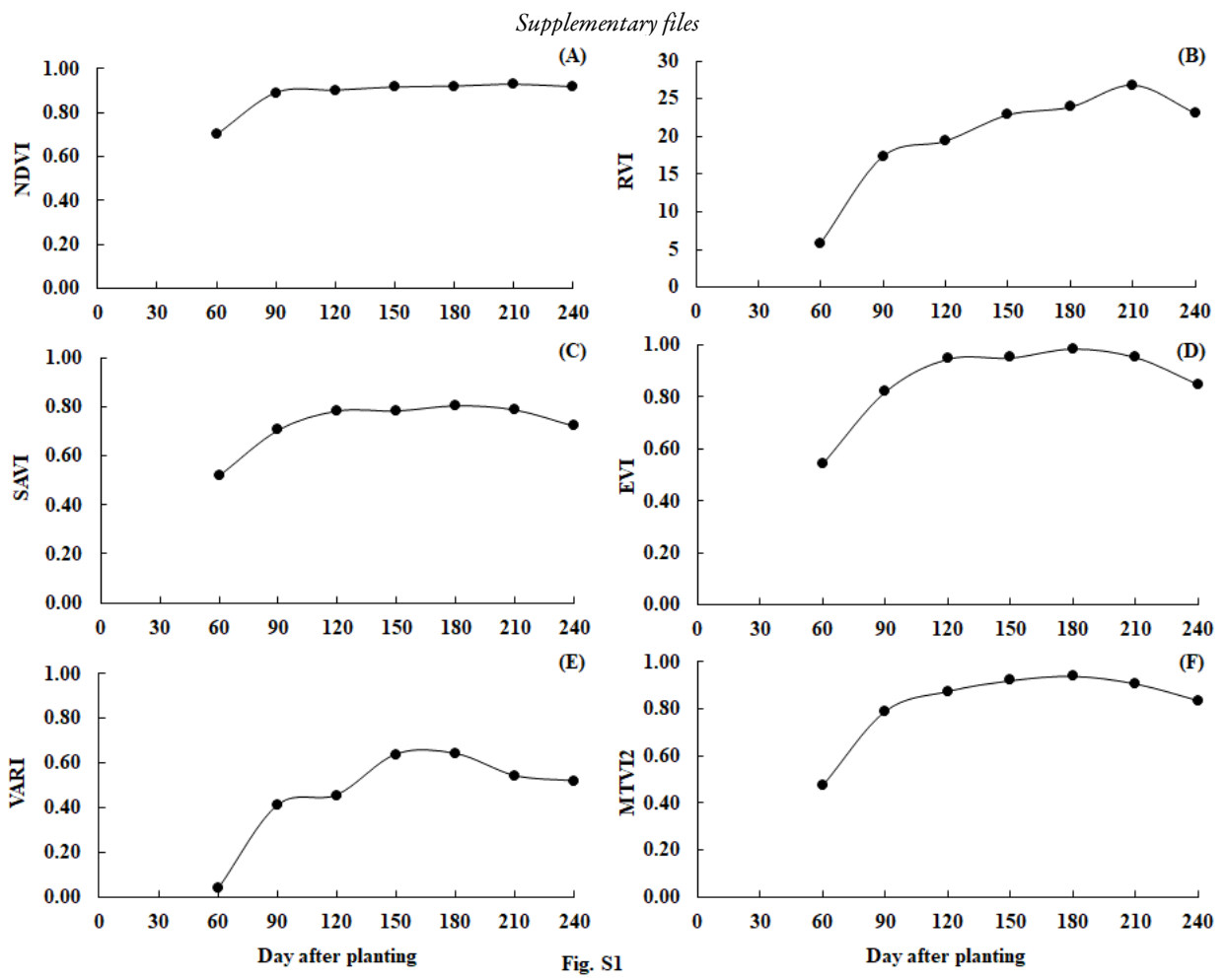

Fig. Supplementary 1. NDVI (A), RVI (B), SAVI (C), EVI (D), VARI (E) and MTVI2 (F) vegetation indices in each time period after planting date
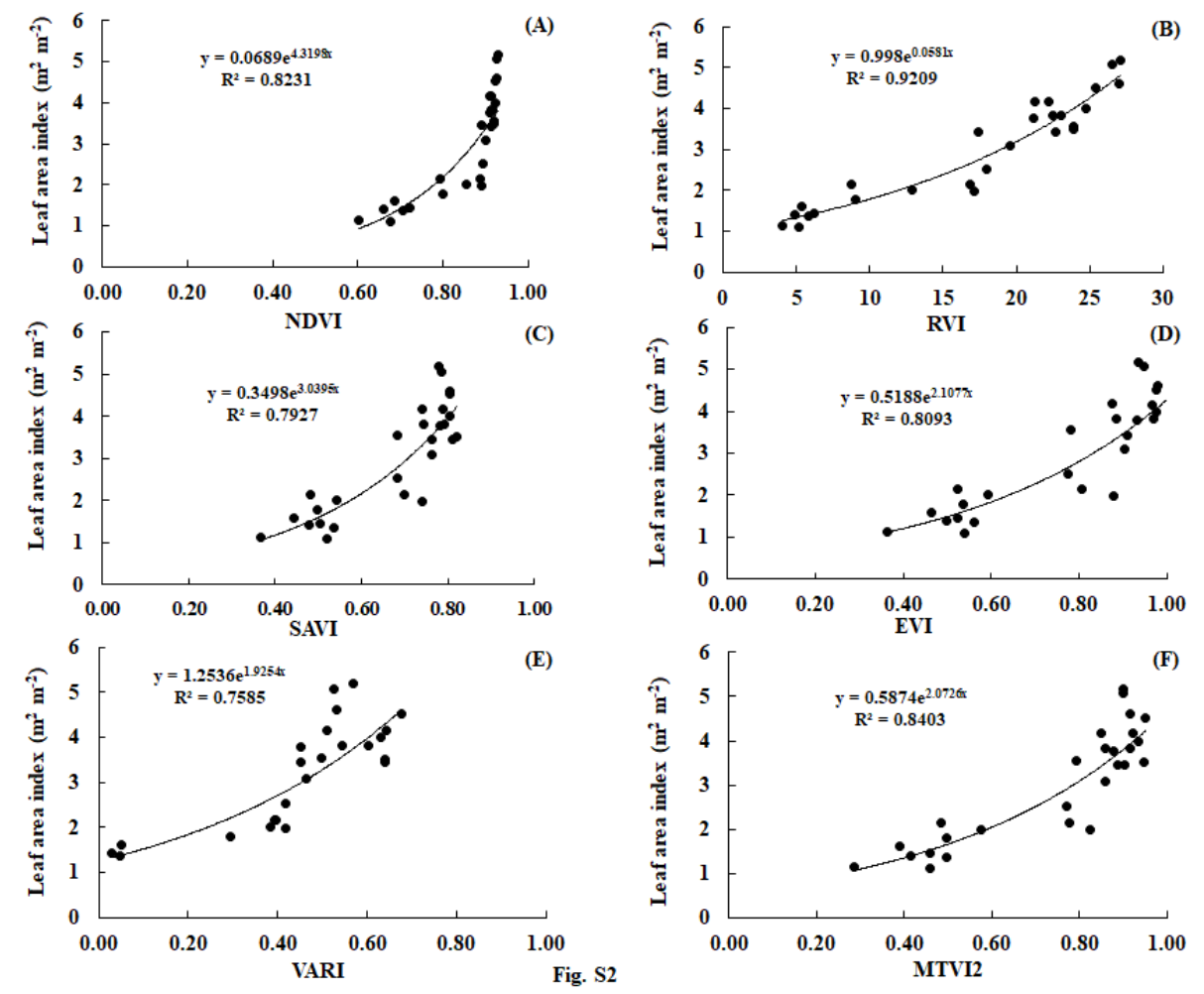

Fig. Supplementary 2. Relationships between NDVI and LAI (A), RVI and LAI (B), SAVI and LAI (C), and LAI EVI (D), VARI and LAI (E) and MTVI2 and LAI (F) in cassava under different water regimes 
Supplementary files
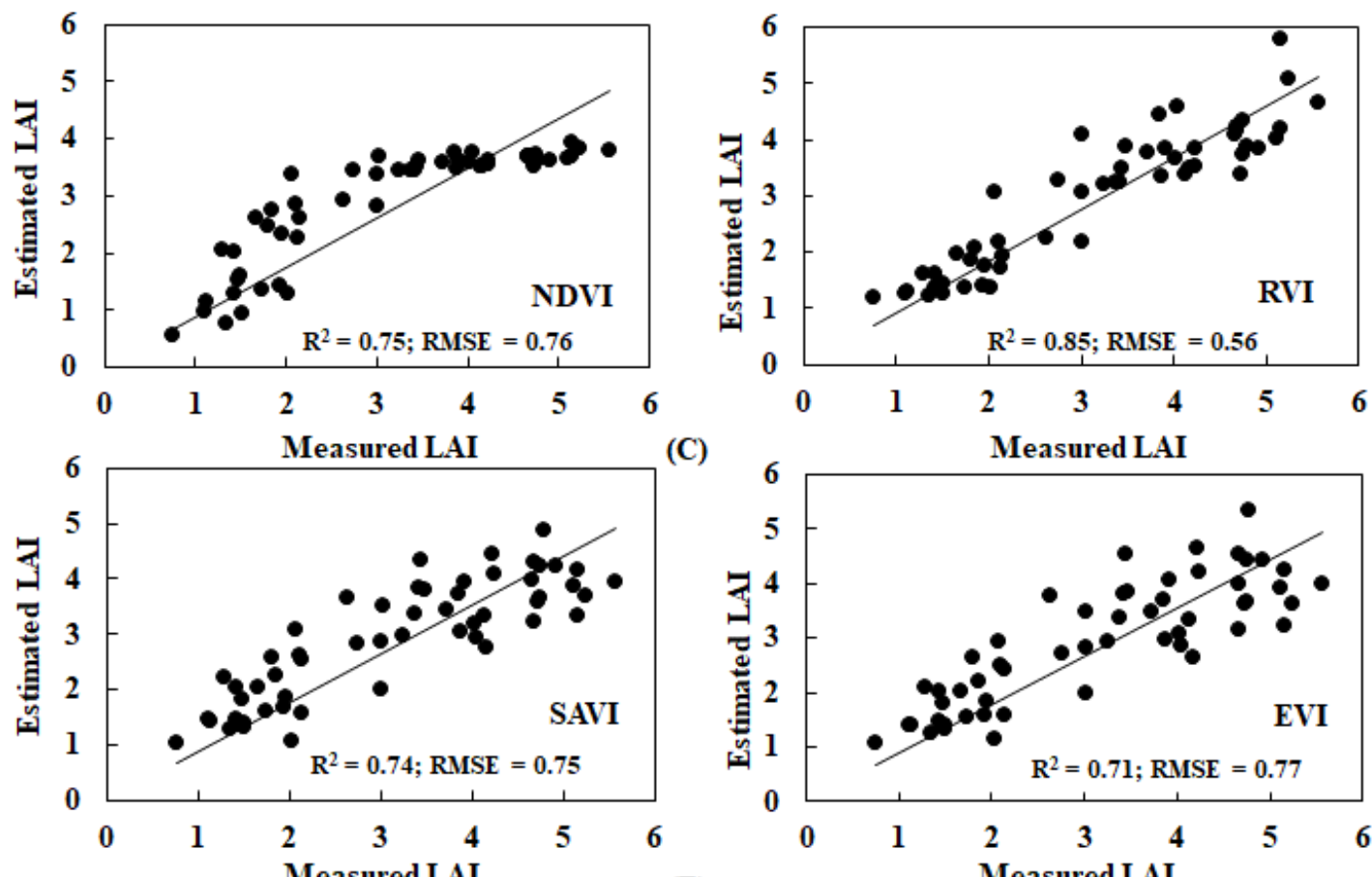

(C)

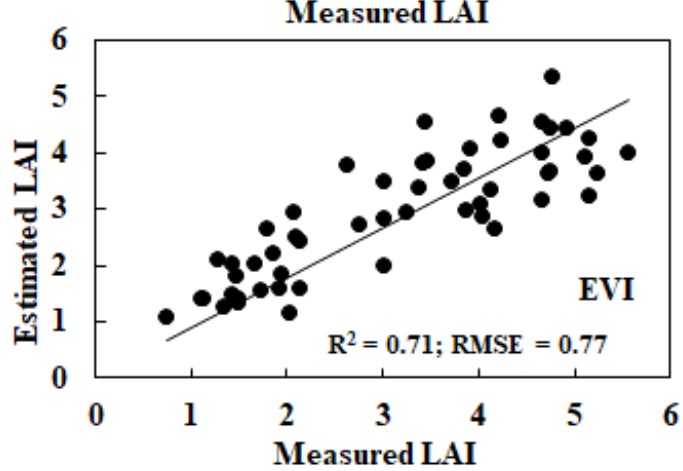

(D)

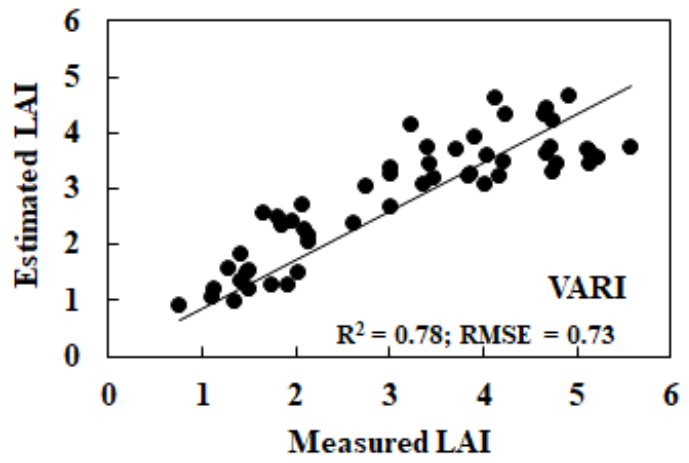

(E)

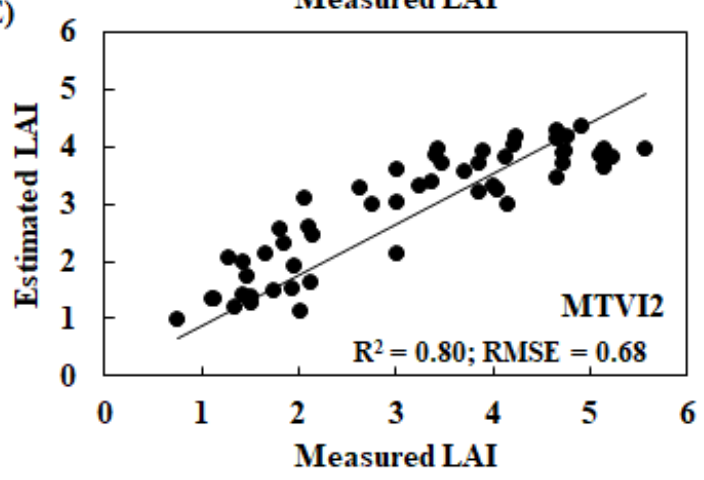

(F)

Fig. Supplementary 3. Calibration on NDVI (A), RVI (B), SAVI (C), EVI (D), VARI (E) and MTVI2 (F) vegetation indices using LAI parameter 